\title{
Związek układu serotoninergicznego i układu sercowo-naczyniowego
}

\section{Association between serotonergic and cardiovascular systems}

\author{
Karolina Semczuk-Kaczmarek ${ }^{1}$, Krzysztof J. Filipiak ${ }^{1}$, Anna Szymańska-Tutak ${ }^{2}$ \\ Anna E. Płatek ${ }^{1,3}$, Filip M. Szymański ${ }^{1}$, Anna Ryś ${ }^{1}$ \\ ${ }^{1}$ I Katedra i Klinika Kardiologii Warszawskiego Uniwersytetu Medycznego \\ ${ }^{2}$ Katedra i Klinika Ortopedii i Traumatologii Narządu Ruchu Warszawskiego Uniwersytetu Medycznego \\ ${ }^{3}$ Katedra i Zakład Patologii Ogólnej i Doświadczalnej Warszawskiego Uniwersytetu Medycznego
}

\section{Streszczenie}

Serotonina (5-HT) odgrywa istotną rolę w regulacji układu sercowo-naczyniowego. Leki wpływające na układ serotoninergiczny powszechnie stosuje się w terapii depresji, migreny, choroby Parkinsona czy otyłości. W zależności od rodzaju aktywowanego receptora 5-HT i jego lokalizacji przyjmowanie tych związków może prowadzić do ostrych i przewlekłych skutków. Przykładem takiego oddziaływania jest ostra odpowiedź kardiologiczna na serotoninę, zwana odruchem Bezolda-Jarisha, która prowadzi do bradykardii i hipotonii. Przewlekła ekspozycja na nadmiar serotoniny może natomiast łączyć się z włóknieniem i zwyrodnieniem zastawek serca. W artykule omówiono wpływ aktywacji poszczególnych receptorów 5-HT na układ sercowo-naczyniowy, działania niepożądane stosowanych leków, a także wskazano nowe możliwości terapii.

Słowa kluczowe: serotonina, remodeling sercowo-naczyniowy, zwyrodnienie zastawek, włóknienie, odruch Bezolda-Jarischa

Folia Cardiologica 2018; 13, 5: 420-427

\section{Wstęp}

Leki działające na układ serotoninergiczny mają różnorodne zastosowanie w medycynie. Agoniści receptora 5-HT $\mathrm{T}_{1 \mathrm{D} / \mathrm{B}}$ tryptany - znalazły zastosowanie w leczeniu migrenowego bólu głowy. Preparatem podawanym w łagodzeniu nudności i wymiotów towarzyszących między innymi chemioterapii nowotworów jest ondansetron - antagonista receptora $5-\mathrm{HT}_{3}$. Inhibitory wychwytu zwrotnego serotoniny (SSRI, selective serotonin reuptake inhibitor) są powszechnie używane w leczeniu depresji. Niegdyś obiecujące efekty w leczeniu otyłości zdawała się wykazywać cząsteczka stymulująca wydzielanie serotoniny - deksfenfluramina. Jednak szczegółowe badania wykazały, że wśród otyłych pacjentów leczonych dłużej niż 4 miesiące deksfenfluraminą znacznie się zwiększyła zapadalność na pierwotne nadciśnienie płucne i nabyte wady serca, co wpłynęło na wycofanie tego leku z rynku [1]. Podobne objawy występowały u pacjentów z chorobą Parkinsona leczonych kabergoliną. Zmiany wywołane przez wymienione związki są podobne do obserwowanych w przypadku rakowiaka - guza neuroendokrynnego wydzielającego dużą ilość serotoniny. W 2015 roku na rynku amerykańskim zarejestrowano nowy lek stosowany w zespole obniżonego popędu seksualnego u kobiet (HSDD, hypoactive sexual desire disorder) - flibanseryna (preparat Addyi ${ }^{\circledR}$ ), który przy przewlekłym podawaniu zwiększa liczbę satysfakcjonujących, zakończonych orgazmem kontaktów seksualnych, podwyższa libido, a w swoim działaniu, oprócz bycia częściowym agonistą receptorów dopaminergicznych $\mathrm{D}_{4}$, jest też agonistą receptorów serotoninowych 5- $\mathrm{HT}_{1 \mathrm{~A}}$ oraz

Adres do korespondencji: lek. Karolina Semczuk-Kaczmarek, I Katedra i Klinika Kardiologii, Warszawski Uniwersytet Medyczny, ul. Banacha 1a, 02-097 Warszawa, tel. 2259919 58, faks 2259919 57, e-mail: karolina.semczuk-kaczmarek@wum.edu.pl 
antagonistą receptorów serotoninowych 5- $\mathrm{HT}_{2 \mathrm{~A}}$. Potencjalne działanie sercowo-naczyniowe tego preparatu, jak i wielu innych leków wpływających na układ serotoninergiczny w ośrodkowym układzie nerwowym nie zostało dotychczas zbadane.

Celem tego krótkiego przeglądu jest omówienie wpływu serotoniny i jej receptorów na remodeling układu sercowo-naczyniowego: przerost mięśnia sercowego, włóknienie i zwyrodnienie zastawek serca.

\section{Serotonina - synteza, metabolizm, mechanizm działania}

U ssaków 90\% serotoniny jest zlokalizowane w komórkach enterochromatofilnych przewodu pokarmowego, gdzie powstaje ona z cząsteczki L-tryptofanu pod wpływem hydroksylazy tryptofanowej [2]. We krwi obwodowej serotonina występuje w trombocytach, które nie biorą udziału w jej syntezie, ale mogą gromadzić serotoninę dzięki wykorzystaniu aktywnego mechanizmu transportu serotoniny (SERT, serotonin transporter) i przechowywać razem z wapniem i trifosforanem adenozyny (ATP, adenosine triphosphate) w pęcherzykach wydzielniczych. Po uwolnieniu z płytek serotonina wywołuje efekty biologiczne przez interakcję $z$ receptorami błonowymi.

Serotonina jest metabolizowana przez enzym monoaminooksydazę (MAO, monoamine oxidase). Bezpośrednim produktem tej reakcji jest aldehyd 5-hydroksyindolooctowy, który później z pomocą dehydrogenazy aldehydowej zostaje utleniony do kwasu 5-hydroksyindolooctowego (5-HIAA, 5-hydroxyindoleacetic acid). Dobowe wydalanie 5-HIAA może być testem używanym w diagnostyce guzów wydzielających serotoninę.

Obecnie rozpoznano receptory 5-HT należące do siedmiu rodzin. Sześć z nich obejmuje receptory związane z białkiem $\mathrm{G}$, a jedna - kanał jonowy $\mathrm{Na}^{+} / \mathrm{K}^{+}$należący do rodziny receptorów nikotyna/GABA $A_{A}$. Na podstawie choćby samego rozmieszczenia receptorów 5-HT można wnioskować o ich roli w regulacji układu sercowo-naczyniowego. Omówienie lokalizacji i funkcji receptorów serotoninowych przedstawiono w tabeli 1.

\section{Rola serotoniny w układzie sercowo-naczyniowym}

Pobudzenie mechano- i chemoreceptorów zlokalizowanych na zakończeniach włókien czuciowych nerwów błędnych w sercu wyzwala odruch Bezolda-Jarischa (BJR, Bezold-Jarisch reflex), objawiający się gwałtownym i znacznym spadkiem częstotliwości akcji serca oraz ciśnienia krwi, a także rozkurczem naczyń obwodowych. Odruch ten składa się z trzech faz: w pierwszej dochodzi do pobudzenia receptorów $5-\mathrm{HT}_{3}$ zlokalizowanych na dośrodkowych włóknach parasympatycznych oraz do blokady pobudzeń
Tabela 1. Rozmieszczenie i funkcja receptorów serotoninowych

\begin{tabular}{|c|c|c|}
\hline $\begin{array}{l}\text { Podtyp } \\
\text { receptora }\end{array}$ & Występowanie & Funkcja \\
\hline $5-\mathrm{HT}_{1 \mathrm{~B}}$ & $\begin{array}{l}\text { Mięśnie gładkie naczyń } \\
\text { Śródbłonek naczyniowy }\end{array}$ & $\begin{array}{l}\text { Wazokonstrykcja } \\
\text { Wazodylatacja }\end{array}$ \\
\hline $5-\mathrm{HT}_{2 \mathrm{~A}}$ & $\begin{array}{l}\text { Płytki krwi } \\
\text { Mięśnie gładkie naczyń }\end{array}$ & $\begin{array}{l}\text { Agregacja płytek } \\
\text { Wazokonstrykcja }\end{array}$ \\
\hline $5-\mathrm{HT}_{2 \mathrm{~B}}$ & $\begin{array}{l}\text { Śródbłonek naczyniowy } \\
\text { Kardiomiocyty i fibroblasty }\end{array}$ & $\begin{array}{l}\text { Wazodylatacja } \\
\text { Włóknienie }\end{array}$ \\
\hline $5-\mathrm{H}_{T 4}$ & Przedsionki i komory serca & Kurczliwość serca \\
\hline $5-\mathrm{H}_{T 7}$ & Mięśnie gładkie tętnic & Wazodylatacja \\
\hline
\end{tabular}

współczulnych, a w konsekwencji - do bradykardii, spadku ciśnienia i poszerzenia naczyń. Następnie naczynioskurczowe działanie serotoniny na receptory $5-\mathrm{HT}_{2 \mathrm{~A}}$ zlokalizowane w ścianie naczyń wywołuje wzrost ciśnienia z odruchową bradykardią. Trzecia faza to ponowny długotrwały spadek ciśnienia spowodowany rozszerzeniem naczyń krwionośnych przez stymulację zlokalizowanych w mięśniówce naczyń receptorów 5- $\mathrm{HT}_{7}, 5-\mathrm{HT}_{2 \mathrm{~B}}$ wspomagających uwalnianie tlenku azotu (NO, nitrogenoxide) ze śródbłonka naczyniowego oraz 5-HT 1 B/D blokujących zwoje autonomiczne [3].

Do wyzwolenia BJR może dochodzić między innymi w czasie omdlenia wazowagalnego, hipowolemii, koronarografii, niedotlenienia i zawału serca, a także reperfuzji mięśnia sercowego [4]. Stwierdzono, że odruch wywołuje niedokrwienie zazwyczaj dolnej i tylno-dolnej ściany serca, co może wynikaćz dużego nagromadzenia zakończeń chemowrażliwych w opisywanych obszarach $[5,6]$. W badaniach przeprowadzonych u pacjentów z dławicą piersiową, którzy nie przebyli zawału serca, dochodziło do nasilenia aktywności nerwu błędnego w czasie indukowanego ćwiczeniami niedokrwienia dolnej ściany serca. W przypadku osób, u których w przeszłości doszło do zawału serca, testy wysiłkowe nie prowadziły już do wyzwolenia odruchu [7]. Przypuszcza się, że BJR w trakcie zawału serca może być wywołany przez prostaglandyny i wolne rodniki uwalniane lokalnie w obrębie niedokrwionego obszaru, które aktywują chemowrażliwe zakończenia nerwów błędnych. Wykazano, że w czasie niedokrwienia mięśnia sercowego i przy niestabilnej dławicy piersiowejstężenie serotoniny zgromadzonej wpłytkach krwi gwałtownie wzrasta, dochodzi do agregacji płytek przy udziale receptora $5-\mathrm{HT}_{2 \mathrm{~A}} \mathrm{i}$ uwolnienia serotoniny, co wywołuje pierwszą fazę BJR [8]. Okazuje się, że również reperfuzja prawej tętnicy wieńcowej u pacjentów dotkniętych ostrym zawałem dolnej ściany serca może być czynnikiem wyzwalającym BJR. Częstość występowania bradykardii i hipotonii w tych przypadkach jest duża, waha się w zakresie 23-100\% [8].

Znaczenie BJR, a w konsekwencji udział serotoniny w tym procesie, w odpowiedzi na niedokrwienie mięśnia sercowego wciąż pozostaje niejasne. Z jednej strony przy 


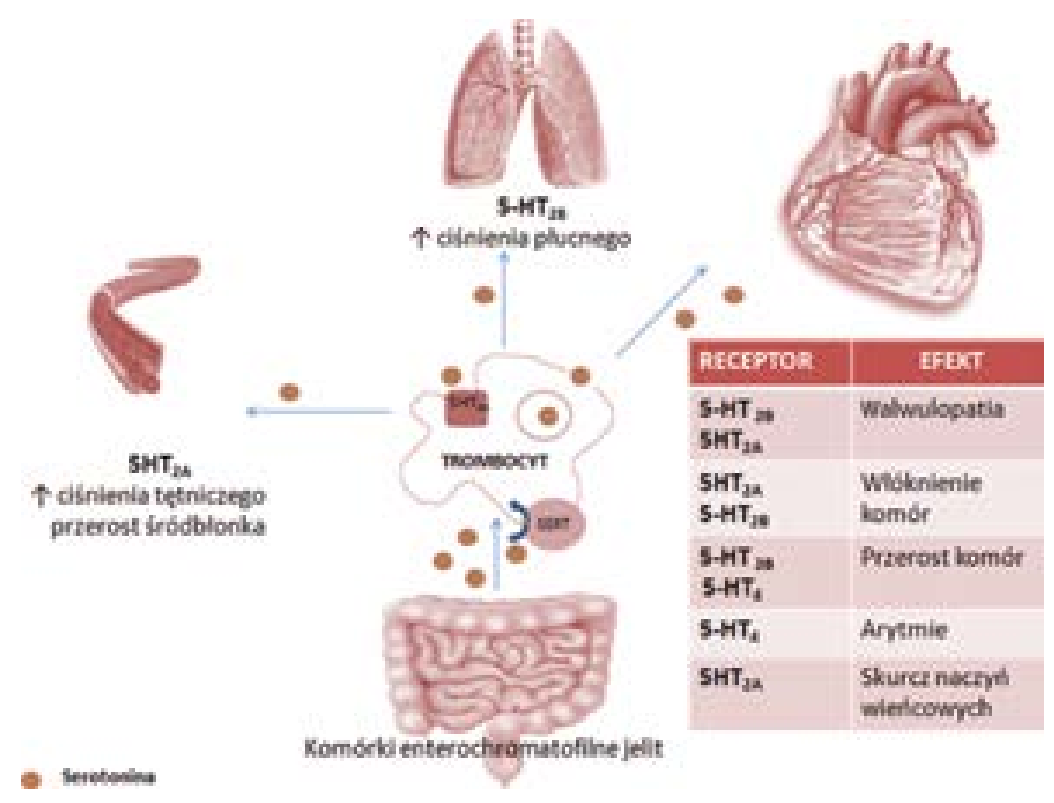

Rycina 1. Rola układu serotoninergicznego w układzie krążenia (zmodyfikowano na podstawie [11])

nadmiernym spadku częstotliwości akcji serca może dojść do nagłej śmierci sercowej często poprzedzonej różnego rodzaju arytmiami [9]. Z drugiej zaś zwiększona aktywność układu przywspółczulnego z następczą bradykardią, obniżeniem kurczliwości serca i rozkurczem naczyń wieńcowych zmniejsza obciążenie następcze, konsumpcję tlenu oraz obszar zawału. Co więcej, wydłużona faza rozkurczu serca zwiększa perfuzję w naczyniach wieńcowych, a ich odruchowy rozkurcz nasila przepływ we wszystkich warstwach mięśnia sercowego [6, 10] (ryc. 1) [11].

\section{Niewydolność serca}

Receptory $5-\mathrm{HT}_{4}$, podobnie jak receptory beta ${ }_{1}$-adrenergiczne, są związane z białkiem Gs. Wykazano, że receptor $5-\mathrm{HT}_{4}$ ulega ekspresji w przedsionkach i komorach; podobnie jak w przypadku innych receptorów serotoninergicznych, poziom jego ekspresji jest dość niski, ale może narastać w przypadku dysfunkcji komór [12]. W przypadku niewydolności serca (HF, heart failure) jego zwiększona aktywność powoduje wzrost kurczliwości i relaksacji mięśnia sercowego (podobnie jak po podaniu izoproterenolu), w niektórych przypadkach może się również przyczyniać do wystąpienia arytmii [13].W szczurzym modelu przerostu serca indukowanego nadciśnieniem tętniczym obserwowano zwiększenie ekspresji receptora $5-\mathrm{HT}_{4}$ już na wczesnych etapach hipertrofii mięśnia sercowego, co korelowało z inotropowo dodatnią odpowiedzią na serotonine [14].

Opierając się na tych założeniach, przeprowadzono badanie metodą podwójnie zaślepionej próby kontrolowane grupa placebo. Pacjenci z HF w klasie II-IV według
New York Heart Association (NYHA) oraz frakcją wyrzutową lewej komory nie wyższą niż 35\% zostali losowo przydzieleni do grupy otrzymującej placebo lub piboserod (antagonista receptora 5- $\mathrm{HT}_{4}$ ) w dawce $80 \mathrm{mg}$ przez 24 tygodnie. Głównym punktem końcowym była ocena frakcji wyrzutowej mierzona przez rezonans magnetyczny serca. Piboserod wyraźnie podnosił frakcję wyrzutową lewej komory (+1,7\%), szczególnie u pacjentów nieprzyjmujących beta-adrenolityków [11].

\section{Przebudowa serca}

Receptory serotoninowe 5- $\mathrm{HT}_{2 \mathrm{~A} / \mathrm{B}}$ zlokalizowane w kardiomiocytach i fibroblastach odgrywają również istotną rolę w remodelingu sercowo-naczyniowym. W przeroście lub dysfunkcji lewej komory powodowanej przez nadciśnienie obserwuje się nadekspresję receptora5- $\mathrm{HT}_{2 \mathrm{~A}}$ [15]. Jego pobudzenie wiąże się z włóknieniem serca, proliferacją i różnicowaniem fibroblastów oraz wydzielaniem kolagenu [16]. W przypadku HF wzrasta również ekspresja receptora $5-\mathrm{HT}_{2 \mathrm{~B}}$. Zaobserwowano pozytywną korelację pomiędzy nadekspresją receptora $5-\mathrm{HT}_{2 \mathrm{~B}}$ na fibroblastach a stężeniem interleukiny 6 (IL-6), czynnika martwicy nowotworów alfa (TNF- $\alpha$, tumor necrosis factor alpha), IL-1 $1 \beta$ oraz noradrenaliny u pacjentów z zastoinową HF [17]. Należy zauważyć, że podobny efekt wywołuje pobudzenie receptora angiotensynowego typu $1\left(\mathrm{AT}_{1}\right)$. Przypuszcza się, że nowe leki będące antagonistami receptora $5-\mathrm{HT}_{2 \mathrm{~B}}$ dzięki spowolnieniu przebudowy serca mogą w przyszłości znaleźć zastosowanie w terapii HF. Zagadnienie to wymaga jednak dalszych, zakrojonych na szeroką skalę badań. 


\section{Stenoza aortalna}

Stężenie serotoniny w osoczu zależy nie tylko od jej uwalniania z aktywowanych płytek krwi, ale także od aktywności monoaminooksydazy (MAO-A), degradującej 5-HT. Wykazano, że kardiomiocyty zawierają dużą ilość MAO-A, a - co ważniejsze - ekspresja genu kodującego MAO jest znacznie zwiększona w przypadku nadciśnienia tętniczego, cukrzycy czy podeszłego wieku [18]. W badaniu Manni i wsp. [19] wykazali zwiększone stężenie serotoniny u pacjentów z ciężką stenozą aortalną. Warto zauważyć, że wzrost jej stężenia był wykrywany we krwi przechodzącej przez zastawkę aortalną, wskazując, że aktywacja płytek krwi i uwalnianie serotoniny następuje przypuszczalnie w tej okolicy. Idąc dalej, można wnioskować, że zwiększone stężenie serotoniny może się rozproszyć w krążeniu wieńcowym i bezpośrednio oddziaływać na tkankę serca. Wzrostowi stężenia serotoniny w osoczu krwi tętniczej towarzyszył wzrost stężenia metabolitu 5-HIAA oraz zwiększenie aktywności płytek, co w mechanizmie dodatniego sprzężenia zwrotnego może utrzymywać jej podwyższone stężenie [20]. Obserwacje te sugerują, że układ serotoninergiczny może uczestniczyć w przebudowie serca i dysfunkcji zastawek również w stenozie aortalnej.

\section{Zespół rakowiaka}

Rakowiak jest rzadkim guzem pochodzenia neuroendokrynnego. Częstość występowania rakowiaków u ludzi szacuje się na 1,2-2,1/100 tys. mieszkańców/rok [21]. Najczęściej lokalizują się w przewodzie pokarmowym (75-85\%), rzadziej w obrębie układu oddechowego (15-25\%). Większość z nich jest bezobjawowa i rozpoznawana przypadkowo. Warto zaznaczyć, że rakowiak przewodu pokarmowego długo może przebiegać bezobjawowo, ponieważ serotonina ulega inaktywacji w hepatocytach. Dopiero gdy rozwiną się przerzuty do wątroby, serotonina nie trafia już do krążenia wrotnego (nie ulega inaktywacji w wątrobie) i wywołuje objawy kliniczne zwane zespołem rakowiaka: napadowe, kilkuminutowe zaczerwienienia twarzy i szyi typu flush połączone z tachykardią, biegunką i skurczem oskrzeli. Ogniska metastatyczne rakowiaka w wątrobie mogą bezpośrednio - przez spływ żylny - zwiększać stężenie serotoniny w prawej komorze serca. Podobnie guzy płuc i przestrzeni zaotrzewnowej wcześniej wywołują zespół rakowiaka, ponieważ wydzielanie substancji czynnych następuje bezpośrednio do krążenia systemowego z pominięciem krążenia wrotnego.

Podstawową rolę w diagnostyce rakowiaków odgrywają testy biochemiczne. Najbardziej specyficznymi i miarodajnymi markerami są: zwiększone wydalanie 5-HIAA z moczem w 24-godzinnym teście i podwyższone stężenie serotoniny w osoczu. Aby ocenić lokalizację guzów, w diagnostyce obrazowej wykorzystuje się ultrasonografię, tomografię komputerową, rezonans magnetyczny oraz scyntygrafię. Leczeniem z wyboru jest chirurgiczne usunięcie guza i okolicznych węzłów chłonnych.

Kardiologiczny zespół rakowiaka (carcinoid heart syndrome), zwany zespołem Hedingera, występuje u ponad 50\% osób z zespołem rakowiaka [22] i z powodu rozwoju prawokomorowej HF stanowi główną przyczynę umieralności chorych z rakowiakiem [23]. U podłoża zmian w układzie krążenia leży najprawdopodobniej przepływ krwi bogatej w serotoninę wydzielaną przez guz [24]. Dochodzi do zwłóknienia wsierdzia prawej części serca, wad zastawki trójdzielnej i pnia płucnego. Lewa część serca jest chroniona przez inaktywującą serotoninę MAO występującą w tkance płucnej.

W przypadku rakowiaka płuca lub obecności prawo-lewego przecieku może dojść również do uszkodzenia wsierdzia i zastawek lewej części serca. Zmniejsza się ruchomość płatków zastawek i ich elastyczność, co bezpośrednio prowadzi do zaburzeń ich koaptacji i w rezultacie najczęściej do niedomykalności, rzadziej do zwężenia zastawki [25]. W rozwijającej się niewydolności prawego serca dominują: pogarszająca się tolerancja wysiłku, duszność, obrzęki, hepatosplenomegalia, gromadzący się w trzeciej przestrzeni płyn przesiękowy, a w konsekwencji sercowa kacheksja. Dodatkowo w tej grupie pacjentów obserwuje się zmiany w EKG - blok prawej odnogi pęczka Hisa (RBBB, right kundle branch block), zaburzenia repolaryzacji mogące wynikać z uszkodzenia zastawek, a także tachykardię zatokowa jako bezpośredni efekt oddziaływania serotoniny na receptory $5-\mathrm{HT}_{4}[11]$.

Przypuszcza się, że zmiany w sercu są konsekwencją około 25\% zgonów. Śmiertelność wśród chorych na rakowiaka jest około 2-krotnie wyższa w przypadku zajęcia serca. $Z$ histologicznego punktu widzenia płytkowate zgrubienia endokardium są zbudowane z miofibroblastów, kolagenu i glukozoaminoglikanów. Dotychczas w żadnej pracy nie wykazano jednoznacznie roli serotoniny w procesie degeneracji zastawek. Wydaje się, że istnieje korelacja między stężeniem serotoniny w osoczu, 5-HIAA w moczu a występowaniem zmian na zastawkach. Mimo to nie można wykluczyć, że serotonina może być tylko markerem wydzielania guza, bez mechanizmu przyczynowego. Konieczne jest przeprowadzenie dalszych badań wyjaśniających, czy blokada syntezy serotoniny lub jej receptorów może zapobiec wystąpieniu kardiologicznego zespołu rakowiaka. Obecnie trwa badanie nad zastosowaniem inhibitora hydroksylazy tryptofanu - telotristatu - w zapobieganiu rozwojowi zespołu rakowiaka.

\section{Leki serotoninergiczne a zastawki serca}

Mimo że jednoznacznie nie ustalono, czy podwyższone stężenie serotoniny bezpośrednio wpływa na rozwój sercowego zespołu rakowiaka, zaobserwowano, że substancje 
będące agonistami receptora $5-\mathrm{HT}_{2 \mathrm{~B}}$ (pergolid, kabergolina) mogą odgrywać rolę wprocesie degeneracji zastawek. U pacjentów przyjmujących te leki zauważono zmiany na zastawkach podobne do obserwowanych w przypadku sercowego zespołu rakowiaka: pogrubiałe obszary będące depozytami aktyno- i wimentyno-dodatnich komórek mięśni gładkich i glikozoaminoglikanów. Zastawki serca cechowały się nadekspresją receptorów $5-\mathrm{HT}_{2 \mathrm{~A}}$ i $5-\mathrm{HT}_{2 \mathrm{~B}}$ przy niewielkiej ekspresji 5- $\mathrm{HT}_{4}$ i SERT. Zaobserwowano również, że zablokowanie receptorów 5- $\mathrm{HT}_{2 \mathrm{~B}}$ u szczurów, a $5-\mathrm{HT}_{2 \mathrm{~A}}$ u owiec hamuje rozwój walwulopatii indukowanej przez pergolid. Blokada receptorów $5-\mathrm{HT}_{2 \mathrm{~B}}$ zapobiega indukowanemu przez transformujący czynnik wzrostu beta (TGF- $\beta$, transforming growth factor $\beta$ ) różnicowaniu miofibroblastów. Obserwacje te otwierają nowy kierunek badań nad rolą antagonisty receptora $5-\mathrm{HT}_{2 \mathrm{~B}}$. W badaniach przeprowadzonych in vitro na komórkach zastawek wykazano, że pobudzenie receptora $5-\mathrm{HT}_{2 \mathrm{~B}}$ prowadzi do stosunkowo niewielkich zmian o charakterze remodelingu [26]. Dopiero obecność sił rozciągających i działanie inhibitorów SERT wzmagają proliferację komórek oraz odkładanie kolagenu [27]. Dodatkowo Sauls i wsp. [28] zauważyli, że serotonina jest wychwytywana przez komórki zawierające SERT, następnie jest w nich metabolizowana lub wykorzystywana jako substrat przez transglutaminaze 2, enzym zaangażowany w proces różnicowania komórek śródbłonka. Ostatnie badania pozwalają sądzić, że działanie tego enzymu prowadzi do remodelingu macierzy zewnątrzkomórkowej.

\section{Układ serotoninergiczny a miażdżycowa przebudowa naczyń}

Sarpogrelat, antagonista receptora $5-\mathrm{HT}_{2 \mathrm{~A}}$, jest lekiem przeciwpłytkowym używanym zamiast klopidogrelu u pacjentów „słabo metabolizujących” cytochrom P450 2C19, niezdolnych do aktywacji proleku. U pacjentów z chorobą wieńcową zwiększa on średnią prędkość przepływu w krążeniu wieńcowym.W badaniach przeprowadzonych na psach i myszach wykazano, że sarpogrelat jako odwrotny agonista receptora $5-\mathrm{HT}_{1 \mathrm{~B}}$ dodatkowo aktywuje śródbłonkową syntazę NO (eNOS, endothelial nitric oxide synthase). Co interesujące, García-Pedraza i wsp. [29] zaobserwowali, że u szczurów leczonych sarpogrelatem stymulacja receptorów $5-\mathrm{HT}_{7}$ i $5-\mathrm{HT}_{10}$ zapobiega wzrostom ciśnienia indukowanym przez układ współczulny. Blokada receptora $5-\mathrm{HT}_{2 \mathrm{~A}}$ może uwrażliwiać komórki mięśni gładkich na wazodylatacyjne działanie pozostałych receptorów serotoninergicznych.

W 2003 roku Hayashi i wsp. [30] udowodnili, że sarpogrelat nie tylko działa na eNOS, ale także równolegle redukuje odkładanie blaszek miażdżycowych u królików z hipercholesterolemią. Potencjalny wpływ tego leku na zmniejszenie proliferacji mięśniówki gładkiej naczyń zaowocował kolejnymi badaniami oceniającymi zastosowanie tego leku w miażdżycy tętnic obwodowych. Podawanie sarpogrelatu po przeprowadzeniu zabiegów endowaskularnych w niedrożnych tętnicach kończyny dolnej redukowało liczbę punktów końcowych, takich jak amputacja kończyny czy zgon. Co więcej, wyniki tego badania wskazują równoważność podawania sarpogrelatu z kwasem acetylosalicylowym (ASA, acetylsalicylic acid), jak i sarpogrelatu z klopidogrelem w zapobieganiu restenozie w odcinku udowo-podkolanowym [31]. Wyniki przedstawionych badań - redukcja hiperplazji neointimy i poprawa funkcji śródbłonka - zachęcają do stosowania sarpogrelatu w miażdżycy kończyn dolnych [32].

\section{Układ serotoninergiczny a zespół metaboliczny}

Serotonina pełni również istotną funkcję w rozwoju zespołu metabolicznego. Pobudzenie receptora $5-\mathrm{HT}_{2 \mathrm{~A}}$ podnosi stężenie glukozy i adrenaliny, zwiększając insulinooporność [33]. Wysokie stężenie glukozy powoduje dysfunkcję śródbłonka, a ostatnie badania pozwalają przypuszczać, że serotonina może odgrywać kluczową rolę w tym procesie. Zaobserwowano, że inkubacja szczurzych komórek pobranych z aorty w wysokim stężeniu glukozy upośledza między innymi wazodylatacyjną funkcję śródbłonka. Z kolei sarpogrelat, zwiększając produkcję NO, wspomaga rozszerzanie naczyń.

W szczurzym modelu cukrzycy typu 1 sarpogrelat nie tylko zmniejszał stężenie glukozy, ale również obniżał ekspresję cząsteczki adhezyjnej komórek śródbłonka i płytek krwi (PECAM-1, platelet endothelial cell adhesion molecule 1), ograniczając ryzyko zakrzepicy. We wspomnianych badaniach podkreśla się rolę receptora $5-\mathrm{HT}_{2 \mathrm{~A}}$ w regulacji naczynioruchowej i współdziałaniu komórek śródbłonka z komórkami mięśni gładkich.

\section{Układ serotoninergiczny a wrodzone wady serca}

Serotonina jest neuroprzekaźnikiem, który działa jako czynnik regulujący w krytycznym okresie rozwoju zarodków. Serce płodu ulega przemianom morfologicznym w ciągu pierwszych 112 dni rozwoju. Morfogeneza serca zależy od migracji, przeżycia i proliferacji komórek nerwowych, które są regulowane przez serotoninę, głównie za pośrednictwem receptora 5- $\mathrm{HT}_{2 \mathrm{~B}}$. Dodatkowo serotonina jest jednym z czynników w kaskadzie sygnalizacyjnej prowadzącej do ustalenia lateralizacji w komórkach serca. Podczas embriogenezy serotonina z krwi matczynej dostaje się do krwioobiegu płodu przez znajdujący się w łożysku SERT. Selektywne inhibitory zwrotnego wychwytu serotoniny hamują SERT w komórkach serca płodu, co zmniejsza transport serotoniny do komórek i może, teoretycznie, zaburzyć normalny 
rozwój serca. Ponadto SSRI mogą hamować ekspresję SERT w łożysku,ograniczając transport serotoniny i/lub innych ważnych czynników wzrostu przez łożysko [34]. Selektywne inhibitory zwrotnego wychwytu serotoniny uważano za leki bezpieczne w ciąży do momentu opublikowania raportu przygotowanego przez producenta paroksetyny, który mówił o 1,5-krotnie większym ryzyku wystąpienia wad serca, głównie ubytków przegrody przedsionkowej (ASD, atrial septal defect) i międzykomorowej (VSD, ventricular septal defect), u dzieci narażonych w okresie życia płodowego na działanie paroksetyny. Amerykańska Agencja ds. Żywności i Leków (FDA, Food and Drug Administration) zmieniła klasyfikację paroksetyny stosowanej w ciąży z kategorii $C$ na $D$ oraz wydała zalecenia, w których proponowano rozważenie odstawienia tego leku lub zmniejszenie dawki u kobiet w ciąży w celu zmniejszenia ryzyka wad płodu. Podobnie w dużym europejskim badaniu opartym na EUROCAT (European Surveillance of Congenital Anomalies) wykazano, że ekspozycja na SSRI wiąże się z istotnie statystycznym ryzykiem rozwoju poważnej wady serca: tetralogią Fallota, anomalią Ebsteina, natomiast wady typu ASD lub VSD znajdowały się na granicy istotności statystycznej [35]. Przypuszcza się, że stosowanie paroksetyny w ciąży może się wiązać z częstszym występowaniem ASD, natomiast terapia fluoksetyną - z rozwojem VSD. Różnice w farmakogenetyce mogą wyjaśnić, dlaczego tylko u niektórych płodów narażonych na SSRI rozwijają się wady serca. Wrodzone wady serca nie są chorobami pospolitymi (8/tys. żywo urodzonych niemowląt), liczba płodów narażonych na SSRI zaś jest stosunkowo niska. Ze względu na to brakuje bezstronnych, poprawnych metodologicznie badań, które mogłyby jednoznacznie określić wpływ terapii SSRI na ryzyko wystąpienia wrodzonej wady serca.

\section{Podsumowanie}

W wyniku przeprowadzonej analizy należy uznać, że układ serotoninergiczny wpływa na remodeling sercowo-naczyniowy: przerost mięśnia sercowego, włóknienie i zwyrodnienie zastawek serca. Z punktu widzenia lekarza kardiologa warto zatem na obecnym etapie wiedzy pamiętać, że:

- w przypadku HF zwiększona aktywność receptora 5- $\mathrm{HT}_{4}$ powoduje wzrost kurczliwości i relaksacji mięśnia sercowego, w niektórych przypadkach może również powodować arytmie;

- w przeroście/dysfunkcji lewej komory powodowanej przez nadciśnienie tętnicze obserwuje się nadekspresję receptora $5-\mathrm{HT}_{2 \mathrm{~A}}$ prowadzącą do włóknienia serca;

- substancje będące agonistami receptorów 5- $\mathrm{HT}_{2 \mathrm{~B}}$ moga odgrywać rolę w procesie degeneracji zastawek;

- zastosowanie SSRI u kobiet w ciąży może się wiązać z ryzykiem wystąpienia wrodzonych wad serca u płodu;

- badania z użyciem sarpogrelatu, antagonisty receptora 5- $\mathrm{HT}_{2 \mathrm{~A}}$, wskazują na potencjalną możliwość zastosowania tego leku w terapii nadciśnienia tętniczego, miażdżycy czy zespołu metabolicznego;

- analizowane zagadnienia wymagają przeprowadzenia dalszych, zakrojonych na szerszą skalę badań, ale warto odnotować, że coraz powszechniejsze stosowanie SSRI w praktyce, jak też wprowadzanie nowych leków opartych na mechanizmach serotoninowych wymaga szczególnej czujności ze strony kardiologów i farmakologów klinicznych.

\section{Konflikt interesów}

Autorzy nie zgłaszają konfliktu interesów.

\section{Abstract}

Serotonin plays an important role in regulating the cardiovascular system. Drugs widely used in the treatment of depression, migraine, Parkinson's disease or obesity affect the serotonergic system. The use of these compounds causes both acute and chronic effects, depending on the type of activated 5-HT receptor and its location. An acute cardiac response to 5-HT, known as Bezold-Jarisch reflex, leads to bradycardia and hypotension. The chronic contribution of serotonin may be associated with fibrosis and cardiac valve degeneration. This article analyses the impact of 5-HT receptors activation on the cardiovascular system and describes side effects of this activation and new therapies targeting this system.

Key words: serotonin, cardiovascular remodeling, valve degeneration, fibrosis, Bezold-Jarisch reflex

Folia Cardiologica 2018; 13, 5: 420-427 


\section{Piśmiennictwo}

1. Białkowska M. Leczenie farmakologiczne otyłości - przeszłość, teraźniejszość, przyszłość. Post Nauk Med. 2000; 3: 10-14.

2. Katzung BG, Masters SB, Trevor A. Farmakologia ogólna i kliniczna. Tomy 1-2. Czelej, Lublin 2012: 321-327.

3. Ramage AG, Villalón CM. 5-hydroxytryptamine and cardiovascular regulation. Trends Pharmacol Sci. 2008; 29(9): 472-481, doi: 10.1016/j. tips.2008.06.009, indexed in Pubmed: 19086344.

4. Chiladakis JA, Patsouras N, Manolis AS. The Bezold-Jarisch reflex in acute inferior myocardial infarction: clinical and sympathovagal spectral correlates. Clin Cardiol. 2003; 26(7): 323-328, indexed in Pubmed: 12862298.

5. Thames MD, Klopfenstein HS, Abboud FM, et al. Preferential distribution of inhibitory cardiac receptors with vagal afferents to the inferoposterior wall of the left ventricle activated during coronary occlusion in the dog. Circ Res. 1978; 43(4): 512-519, doi: 10.1161/01. res.43.4.512, indexed in Pubmed: 688555.

6. Mark AL. The Bezold-Jarisch reflex revisited: clinical implications of inhibitory reflexes originating in the heart. J Am Coll Cardiol. 1983; 1(1): 90-102, doi: 10.1016/s0735-1097(83)80014-x, indexed in Pubmed: 6826948.

7. Kawasaki T, Azuma A, Kuribayashi T, et al. Enhanced vagal modulation and exercise induced ischaemia of the inferoposterior myocardium. Heart. 2006; 92(3): 325-330, doi: 10.1136/hrt.2005.063230, indexed in Pubmed: 15939725.

8. Shimizu Y, Minatoguchi S, Hashimoto K, et al. The role of serotonin in ischemic cellular damage and the infarct size-reducing effect of sarpogrelate, a 5-hydroxytryptamine-2 receptor blocker, in rabbit hearts. J Am Coll Cardiol. 2002; 40(7): 1347-1355, indexed in Pubmed: 12383585.

9. Wei JY, Markis JE, Malagold M, et al. Cardiovascular reflexes stimulated by reperfusion of ischemic myocardium in acute myocardial infarction. Circulation. 1983; 67(4): 796-801, indexed in Pubmed: 6825235.

10. Clozel JP, Pisarri TE, Coleridge HM, et al. Reflex coronary vasodilation evoked by chemical stimulation of cardiac afferent vagal $C$ fibres in dogs. J Physiol. 1990; 428: 215-232, doi: 10.1113/jphysiol.1990. sp018208, indexed in Pubmed: 2231410.

11. Ayme-Dietrich E, Aubertin-Kirch G, Maroteaux L, et al. Cardiovascular remodeling and the peripheral serotonergic system. Arch Cardiovasc Dis. 2017; 110(1): 51-59, doi: 10.1016/j.acvd.2016.08.002, indexed in Pubmed: 28017279.

12. Qvigstad E, Brattelid T, Sjaastad I, et al. Appearance of a ventricular 5-HT4 receptor-mediated inotropic response to serotonin in heart failure. Cardiovasc Res. 2005; 65(4): 869-878, doi: 10.1016/j.cardiores.2004.11.017, indexed in Pubmed: 15721867.

13. Levy FO, Qvigstad E, Krobert KA, et al. Effects of serotonin in failing cardiac ventricle: signalling mechanisms and potential therapeutic implications. Neuropharmacology. 2008; 55(6): 1066-1071, doi: 10.1016/j.neuropharm.2008.07.010, indexed in Pubmed: 18675829

14. Birkeland JA, Swift F, Tovsrud N, et al. Serotonin increases L-type Ca2+ current and SR Ca2+ content through 5-HT4 receptors in failing rat ventricular cardiomyocytes. Am J Physiol Heart Circ Physiol. 2007; 293(4): 2367-2376, doi: 10.1152/ajpheart.01375.2006, indexed in Pubmed: 17660386.

15. Ayme-Dietrich E, Marzak H, Lawson R, et al. Contribution of serotonin to cardiac remodeling associated with hypertensive diastolic ventricular dysfunction in rats. J Hypertens. 2015; 33(11):
2310-2321, doi: 10.1097/HJH.0000000000000695, indexed in Pubmed: 26259125.

16. Yabanoglu S, Akkiki M, Seguelas $\mathrm{MH}$, et al. Platelet derived serotonin drives the activation of rat cardiac fibroblasts by $5-\mathrm{HT} 2 \mathrm{~A}$ receptors. J Mol Cell Cardiol. 2009; 46(4): 518-525, doi: 10.1016/j. yjmcc.2008.12.019, indexed in Pubmed: 19167402.

17. Jaffré F, Callebert J, Sarre A, et al. Involvement of the serotonin 5-HT2B receptor in cardiac hypertrophy linked to sympathetic stimulation: control of interleukin-6, interleukin-1beta, and tumor necrosis factor-alpha cytokine production by ventricular fibroblasts. Circulation. 2004; 110(8): 969-974, doi: 10.1161/01.CIR.0000139856.20505.57, indexed in Pubmed: 15302781.

18. Marzak H, Ayme-Dietrich E, Lawson R, et al. Old spontaneously hypertensive rats gather together typical features of human chronic left-ventricular dysfunction with preserved ejection fraction. J Hypertens. 2014; 32(6): 1307-1316, doi: 10.1097/HJH.0000000000000159, indexed in Pubmed: 24786294.

19. Manni ME, Zazzeri M, Musilli C, et al. Exposure of cardiomyocytes to angiotensin II induces over-activation of monoamine oxidase type A: implications in heart failure. Eur J Pharmacol. 2013; 718(1-3): 271-276, doi: 10.1016/j.ejphar.2013.08.022, indexed in Pubmed: 24012905.

20. Rouzaud-Laborde C, Delmas C, Pizzinat N, et al. Platelet activation and arterial peripheral serotonin turnover in cardiac remodeling associated to aortic stenosis. Am J Hematol. 2015; 90(1): 15-19, doi: 10.1002/ajh.23855, indexed in Pubmed: 25242620.

21. Klöppel G, Perren A, Heitz PU. The gastroenteropancreatic neuroendocrine cell system and its tumors: the WHO classification. Ann NY Acad Sci. 2004; 1014: 13-27, doi: 10.1196/annals.1294.002, indexed in Pubmed: 15153416.

22. Bhattacharyya S, Davar J, Dreyfus G, et al. Carcinoid heart disease. Circulation. 2007; 116(24): 2860-2865, doi: 10.1161/circulationaha.107.701367.

23. Westberg G, Wängberg B, Ahlman $\mathrm{H}$, et al. Prediction of prognosis by echocardiography in patients with midgut carcinoid syndrome. Br J Surg. 2001; 88(6): 865-872, doi: 10.1046/j.0007-1323.2001.01798.x, indexed in Pubmed: 11412260.

24. Bhattacharyya S, Toumpanakis C, Chilkunda D, et al. Risk factors for the development and progression of carcinoid heart disease. Am J Cardiol. 2011; 107(8): 1221-1226, doi: 10.1016/j.amjcard.2010.12.025, indexed in Pubmed: 21296329.

25. Pellikka PA, Tajik AJ, Khandheria BK, et al. Carcinoid heart disease. Clinical and echocardiographic spectrum in 74 patients. Circulation. 1993; 87(4): 1188-1196, doi: 10.1161/01.cir.87.4.1188, indexed in Pubmed: 7681733.

26. Barzilla JE, Acevedo FE, Grande-Allen KJ. Organ culture as a tool to identify early mechanisms of serotonergic valve disease. J Heart Valve Dis. 2010; 19(5): 626-635, indexed in Pubmed: 21053743.

27. Balachandran K, Bakay MA, Connolly JM, et al. Aortic valve cyclic stretch causes increased remodeling activity and enhanced serotonin receptor responsiveness. Ann Thorac Surg. 2011; 92(1): 147-153, doi: 10.1016/j.athoracsur.2011.03.084, indexed in Pubmed: 21718840.

28. Sauls K, de Vlaming A, Harris BS, et al. Developmental basis for filamin-A-associated myxomatous mitral valve disease. Cardiovasc Res. 2012; 96(1): 109-119, doi: 10.1093/cvr/cvs238, indexed in Pubmed: 22843703. 
29. García-Pedraza JÁ, García M, Martín ML, et al. The role of endothelium-derived hyperpolarizing factor and cyclooxygenase pathways in the inhibitory serotonergic response to the pressor effect elicited by sympathetic stimulation in chronic sarpogrelate treated rats. Eur J Pharmacol. 2014; 731: 80-87, doi: 10.1016/j.ejphar.2014.02.043, indexed in Pubmed: 24675150.

30. Hayashi T, Sumi D, Matsui-Hirai $\mathrm{H}$, et al. Sarpogrelate $\mathrm{HCl}$, a selective 5-HT2A antagonist, retards the progression of atherosclerosis through a novel mechanism. Atherosclerosis. 2003; 168(1): 23-31, doi: 10.1016/s0021-9150(03)00054-6, indexed in Pubmed: 12732383.

31. Chen YX, Wang WD, Song XJ, et al. Prospective randomized study of sarpogrelate versus clopidogrel-based dual antiplatelet therapies in patients undergoing femoropopliteal arterial endovascular interventions: preliminary results. Chin Med J (Engl). 2015; 128(12): 1563-1566, doi: 10.4103/0366-6999.158285, indexed in Pubmed: 26063354.

32. Miyazaki M, Higashi Y, Goto C, et al. Sarpogrelate hydrochloride, a selective 5-HT2A antagonist, improves vascular function in patients with peripheral arterial disease. J Cardiovasc Pharmacol. 2007; 49(4): 221-227, doi: 10.1097/FJC.0b013e3180325af3, indexed in Pubmed: 17438407.

33. Takishita E, Takahashi A, Harada N, et al. Effect of sarpogrelate hydrochloride, a 5-HT2 blocker, on insulin resistance in Otsuka Long-Evans Tokushima fatty rats (OLETF rats), a type 2 diabetic rat model. J Cardiovasc Pharmacol. 2004; 43(2): 266-270, doi: 10.1097/00005344200402000-00015, indexed in Pubmed: 14716215.

34. Daud ANA, Bergman JEH, Kerstjens-Frederikse WS, et al. The risk of congenital heart anomalies following prenatal exposure to serotonin reuptake inhibitors - is pharmacogenetics the key? Int J Mol Sci. 2016; 17(8), doi: 10.3390/ijms17081333, indexed in Pubmed: 27529241.

35. Wemakor A, Casson K, Garne E, et al. Selective serotonin reuptake inhibitor antidepressant use in first trimester pregnancy and risk of specific congenital anomalies: a European register-based study. Eur J Epidemiol. 2015; 30(11): 1187-1198, doi: 10.1007/s10654-0150065-y, indexed in Pubmed: 26148560. 